\title{
Thin Capitalization Rules and Entrepreneurial Capital Structure Decisions
}

Alexandra Maßbaum, Faculty of Business Administration and Economics, University of Paderborn, Germany, E-mail: alexandra.massbaum@notes.upb.de

Caren Sureth, Faculty of Business Administration and Economics, University of Paderborn, Germany, E-mail: csureth@notes.upb.de

\begin{abstract}
Tax planners often choose debt over equity financing. As this has led to increased corporate debt financing, many countries have introduced thin capitalization rules to secure their tax revenues. In a general capital structure model we analyze if thin capitalization rules affect dividend and financing decisions, and whether they can partially explain why corporations receive both debt and equity capital. We model the Belgian, German and Italian rules as examples. We find that the so-called Miller equilibrium and definite financing effects depend significantly on the underlying tax system. Further, our results are useful for the treasury to decide what thin capitalization type to implement.
\end{abstract}

Keywords: business taxation, capital structure, critical income tax rate, financing decision, Miller equilibrium, tax planning, thin capitalization

Manuscript received March 19, 2009, accepted by Rainer Niemann (Accounting) November 2, 2009.

\section{Introduction}

Seen from a tax perspective it is often attractive for shareholders of corporations to provide capital as debt instead of equity capital. This has led to an extensive enlargement of debt financing of corporations (OECD 1987: 8 et seq.). To protect tax revenues, the legislators of many countries have reacted to this development by increasingly implementing so-called thin capitalization rules (e.g., in Italy and the Netherlands, see Gouthière 2005 for an overview of different thin capitalization rules) or by tightening existing rules (e.g., in Germany, Denmark, the UK, Spain, and France). Thin capitalization rules are regulations that limit the corporate tax deductibility of interest paid to shareholders.

Moreover, we observe that corporations issue shares as well as debt. This raises the question of whether thin capitalization rules cancel out the tax shield of debt financing, which may explain the attractiveness of one option over the other. Against this background we investigate how such regulations affect the capital structure decisions of corporate stockholders. We neglect problems of information asymmetry between managers and shareholders in the following. Hence, for simplicity we abstract from principal-agent conflicts.

During the last few decades many authors have contributed to the field of corporate capital structure decisions (for an overview of different capital structure models see Myers 2001 and Graham 2006). In line with neoinstitutional theory, the tax based trade-off theory (e.g., Myers 1984) and the non-tax-oriented pecking-order theory (Donaldson 1961) have gained attention. Here, the theory of Modigliani and Miller (1958) represents a seminal work for many contributions based on neoclassical theory. In this early work, taxes were not included. Many extensions to Modigliani and Miller (1958) take many different aspects into account. Modigliani and Miller (1963) extend their model themselves and integrate, among other aspects, a corporate tax. Miller (1977) completes the model anew and implements an income tax on the shareholder level. In both approaches a classical corporate tax system is assumed.

Furthermore, in some contributions the income tax effects on the capital structure are modeled in a more refined manner. For instance, capital gains taxes and, in turn, the asymmetric taxation of div- 
idends and capital gains are highlighted by Farrar and Selwyn (1967), Brennan (1970), and Schneller (1980). Brennan (1970) and Zechner (1990) assume a progressive tax scale and allowances for interest paid.

Some papers take account of tax policy details in various countries. Swoboda (1991) examines Germany's and Austria's 1991 tax laws in a Miller framework. In this context he considers Germany's corporate tax, income tax and also property tax, local business tax and church tax. Fung and Theobald (1984) consider the 1984 tax laws of France, Germany, the United Kingdom, and the USA. Unlike Swoboda, they restrict themselves to corporate and income taxes. Holland and Steiner (1996) extend Swoboda's approach and investigate the influence of Germany's solidarity surcharge on the capital structure. Laß (1999) models US tax law between 1977 and 1994 as well as German tax law between 1976 and 1998, also using the Miller model. Kruschwitz (2007) models the German tax regime in 2007.

Beyond detailed investigations of different taxes there are many other extensions to the Modigliani and Miller (1958) model. Hodder and Senbet (1990), Graham (2003), and Desai, Foley, and Hines (2004) consider international tax aspects, DeAngelo and Masulis (1980a), DeAngelo and Masulis (1980b), and Graham (2000) take account of non-debt-tax shields, e.g., Kraus and Litzenberger (1973), Haugen and Senbet (1978), Kim (1978) model bankruptcy costs, and Jensen and Meckling (1976) and Leland (1998) integrate agency costs (see Harris and Raviv 1991). Capital structure models under uncertainty are examined by Kim (1982), Zechner (1990), and Swoboda (1991). Miller and Scholes (1978) and Litzenberger and van Horne (1978) consider dividend policy. Schneller (1980) and Graham (2003) offer a model that takes account of different systems to prevent double taxation of dividends. A dynamic model is presented by Fischer, Heinkel, and Zechner (1989).

Beyond this finance-theory-oriented stream of literature we refer to the discussion on intertemporarily neutral capital income taxation and consumption-based tax systems in public finance. The so-called ACE tax has become particularly popular as an investment and financing-neutral tax system with an allowance for corporate equity (ACE) deductible from taxable profits, which represents the opportunity costs of equity capital (Wenger 1983;
Boadway and Bruce 1984; Devereux and Freeman 1991). This system is supposed to be close to the tax politicians' idea of a fair and efficient tax system (Devereux and Freeman 1991: 4-6; Fehr and Wiegard 2003: 298). As Belgium is one of the countries to have introduced an ACE tax and simultaneously tightened the thin capitalization rules (e.g., Gerard 2006) it is interesting to analyze its interdependencies and possible capital structure effects.

Although the literature provides detailed investigations of tax rules, thin capitalization rules have to date only been analyzed by Buettner, Overesch, Schreiber, and Wamser (2006), Overesch and Wamser (2006) and Overesch and Wamser (2009). The authors empirically investigate financing decisions in a multinational firm under a restrictive tax rule for stockholders' debt financing, which is comparable to the German thin capitalization rules. In this work, the main elements of a thin capitalization tax rule are considered without modeling country-specific details of the regulation. Here, neither a specific debt-capital/equity-capital ratio, safe haven, nor a differentiation between profitdependent and profit-independent loans are carried out. A more sophisticated analysis of the influence of thin capitalization rules on entrepreneurial capital structure decisions has not yet been conducted.

To fill this void, we integrate thin capitalization rules into a capital structure decision model in the following analysis. We investigate its influence on corporate financing decisions analytically. It also helps the treasury to decide what type of thin capitalization rule to implement under a given tax setting. Our study can be regarded as a first step towards an empirical study on the influence of specific thin capitalization rules on corporate capital structure and thus provides important information to extend the work of Buettner, Overesch, Schreiber, and Wamser (2006), Overesch and Wamser (2006) and Overesch and Wamser (2009). In contrast to empirical public finance papers that are often lacking a sufficient theoretical foundation or do not account for all relevant tax details (Desai, Foley, and Hines 2004; Mintz and Weichenrieder 2005; Huizinga, Laeven, and Nicodème 2006; Weichenrieder and Windischbauer 2008) we provide a detailed theoretical model. Moreover, future empirical papers could verify whether the optimal financing and dividend policies we derive are actually practised. 
We consider thin capitalization rules that are characterized by a given permitted debt-equity capital ratio because many countries limit debt financing referring to such a permitted ratio. We take the Italian, German, and Belgian rules as examples to study their impact on capital structure decisions. The Italian and the German thin capitalization rules are no longer in force. They have been substituted by rules that restrict interest deduction irrespective of a permitted debt-to-equity ratio in those countries. Nevertheless, there are many countries that apply this type of thin capitalization rule, e.g., Bulgaria, Czech Republic, Denmark, Hungary, Latvia, Lithuania, the Netherlands, Poland, Portugal, Romania, Slovakia, and Slovenia. We refer to Belgium, Germany, and Italy as examples to model all major characteristics of this type of thin capitalization rule. These examples allow us to elaborate the mechanisms at work for different implementations of such rules that are common or discussed in several countries and to show how they interact with different tax systems.

Our analysis can help investors not only to make their dividend and financing decisions under thin capitalization rules with a given permitted debtequity ratio but also to adjust their decisions when tax laws change. Our analysis is representative of all thin capitalization rules that refer to such a permitted debt-equity ratio.

As the financing behavior of investors is crucial for designing thin capitalization rules and as the influence of thin capitalization rules depends on several other tax parameters (corporate tax rate, taxable fraction of dividends and capital gains, permitted ratio of debt to equity capital) it is important for the treasury to know how these rules interact. Analyzing different types of thin capitalization rules and performing sensitivity analyses help the treasury to implement a rule that contributes to a given political aim. Thus, the following investigation of different settings of thin capitalization rules and tax systems is of general relevance for a comprehensive understanding of tax effects on capital structure decisions.

After developing the general model we apply our model to selected countries. We refer to the capital structure model by Miller (1977). Miller investigates the market for debt capital and shows that this market always leads to an equilibrium in which for every company the capital structure is irrelevant to the value of the firm. The same after-tax return arises irrespective of the form of financing because this balances out the advantage that debt capital incurs interest payments that are deductible from the corporate tax base (tax shield) and the advantage that equity capital typically leads to relatively lower income tax burden (Miller 1977: 269 et seq.).

In section 2 we develop a framework for a general capital structure model on the basis of Miller (1977) that includes thin capitalization rules. We integrate the Italian, German and Belgian thin capitalization rules into this model in sections 3 to 5 and analyze whether a Miller equilibrium can emerge. If not, we determine the optimal capital structure and identify the most important valuedriving factors. On the basis of Miller (1977), we refer to a single investor's indifference towards providing capital as a loan or as equity capital to a corporation as a "Miller equilibrium". Note, that in the following, this "equilibrium" is not a general market equilibrium. In section 6 we summarize and draw conclusions.

This article is supplemented with Excel spreadsheets that provide the calculations that have been performed for Belgium, Italy, and Germany. ${ }^{1}$

\section{Capital structure under restricted shareholder debt financing}

\subsection{General assumptions}

In the following we integrate thin capitalization for shareholder debt financing into Miller's capital structure model to derive conclusions about the effectiveness of this regulation for financing decisions in corporations. Our model relies on the following set of assumptions.

We assume a perfect capital market under certainty and identical debit and credit interest rates. The borrower is a domestic corporation. The investors are assumed to be domestic individuals who hold their investment and accordingly the provided capital in private means. On the corporate level taxes on profits are considered. On the shareholder level the individual income tax is taken into account. All investors who have to decide to provide either equity or debt capital are assumed to be shareholders of the underlying corporation. Further we

1 These Excel files can be downloaded from www.businessresearch.org. 
assume that the thin capitalization rule applies to all shareholders and thus to all investors (see Appendix A2).

The interest payment $Z$ amounts to $i C$, where $i$ denotes the market rate of return that can be earned on the capital market and $C$ denotes the amount of debt capital provided by an investor.

On the corporate level dividends are not taxdeductible, whereas interest payments on debt are generally tax-deductible as they are operating expenses. In line with Miller, the case of limited interest deductibility, particularly due to losses, is not considered (Miller 1977: 262). We assume that a fraction $\alpha$ of debt is subject to the thin capitalization rule (see Appendix A2). The permitted debt-to-equity ratio will be denoted by $\mu$ and is assumed to be exceeded. Consequently, not the total amount of interest paid to a shareholder is deductible, but only the interest on the permitted fraction of debt capital multiplied with the corporate equity, thus $i \mu E$. As the thin capitalization rule applies to all shareholders, the shareholder's share in corporate equity is irrelevant. In the following the deductible amount of interest is denoted as the utilized safe haven $H$. Hence,

$$
H= \begin{cases}i \mu E, & \text { if } \alpha C>\mu E ; \\ \alpha i C, & \text { if } 0 \leq \alpha C \leq \mu E .\end{cases}
$$

Equity capital $E$ provided by the shareholder denotes the equity capital that has already been provided prior to the point of time when the financing decision is made. The investor's individual amount of equity is exogenously given. Further, it is assumed that all investors offer the same mix of equity and loans to the corporation and consequently all shareholders have an identical safe haven. It is therefore possible to determine the overall safe haven for all shareholders jointly. It is not necessary to refer to the single shareholder.

Some countries raise additional taxes on profits on the corporate level. National tax rates and tax bases vary significantly. In the following the tax rate of these taxes is denoted by $\tau_{a}$, the tax base by F.

Under income tax law, earned interest is taxable at a fraction $\varepsilon$ with $\varepsilon \in[0,1]$. The capital income from shareholders' invested equity capital consists of distributed dividends of the corporation and realized capital gains. The taxable fraction of dividends $D$ is denoted as $\gamma$ with $\gamma \in[0,1]$.
In the following the sum of retained earnings is given by $G$ (Miller 1977: 268). $G$ is not equal to capital gains as this variable neglects the internal growth caused by reinvesting retained earnings at the internal after-tax yield $i\left(1-\tau_{c}-\tau_{a}\right)$. Further, capital gains are not liable to income tax until they are realized at shareholder level. We have to take account of the time effect arising from the delayed taxation of retained earnings. In the following, the time lag of capital gains taxation compared to dividend taxation and the internal growth effect from retained earnings are both captured in the factor $\theta>0$. It is necessary to implement $\theta$ into our static model to highlight the difference in taxation of dividends and capital gains and the internal growth of retained earnings in present value terms. We obtain

$$
\text { (2) } \theta=\frac{\left(1+i\left[1-\tau_{c}-\tau_{a}\right]\right)^{n}}{\left(1+i_{\tau}\right)^{n}} \text {, }
$$

with $\theta G$ denoting the present value of capital gains. We abstract from increases in value that are caused by speculative developments. Here, $i_{\tau}$ is the aftertax market rate of return that the shareholder is able to earn alternatively on the capital market and is given by $i_{\tau}=\left(1-\tau_{i I}\right) i$. $\tau_{i I}$ denotes the investor's personal tax rate on interest income. If interest income is included in the investor's individual tax assessment, the tax rate $\tau_{i I}$ is equal to the investor's personal income tax rate $\tau_{i}$. If there is a withholding tax on interest income, $\tau_{i I}$ is the withholding tax rate. The variable $n$ denotes the period in years after which the capital gains are realized. We assume that $n$ is exogenously given and hence the investor is not able to decide on the holding period $n$. Furthermore, we assume that only a fraction $\lambda$ of the capital gain is taxable. In total the present value of assessable and taxable capital gains $G$ is $\lambda \theta G$ (see Swoboda 1991: 857, and Laß 1999: 119, who assume that capital gains are tax-exempt).

We abstract from personal allowances, incomerelated expenses, standardized deductions, personal exemptions, special expenses and extraordinary charges in the model when calculating taxable income. We assume there is no income from other sources apart from interest income, dividends, and capital gains. The fraction of interest that is not taxdeductible on the corporate level is requalified as hidden profit distribution and therefore treated as a dividend. Dividends and hidden distributions 
are subject to an income tax rate $\tau_{i D}$, interest payments to an income tax rate $\tau_{i I}$ and capital gains to $\tau_{i G}$. Although the income tax schedule is progressive in many countries, from the shareholders' perspective the income tax rate can be regarded as exogenously given.

\subsection{Integrating taxes}

Now we will formally describe all relevant fiscal rules. In a first step we have to determine the amount of interest that can be deducted when determining the corporate tax base. In total, interest payments amounting to $I$ are paid to the investor:

(3) $I=i C$.

The interest payments can be deducted from the corporate tax base up to an amount of $I_{d}$. Interest payments on a fraction $(1-\alpha)$ of the loans are completely deductible, i.e., $I(1-\alpha)$, whereas interest payments on a fraction $\alpha$ of debt are only deductible in the amount of the safe haven $H$. As we assume the safe haven to be exceeded, it is equal to $i \mu E$.

$$
I_{d}=I(1-\alpha)+H=i C(1-\alpha)+i \mu E .
$$

The amount of non-deductible interest expenses $I_{n d}$ which is requalified as a hidden distribution of profits is

$$
I_{n d}=I-I_{d}=i C \alpha-i \mu E .
$$

The taxable income in terms of corporate tax results from the deduction of debt-capital interest $I_{d}$ from gross profit П. Corporate tax amounts to:

$$
T_{c}=\tau_{c}\left(\Pi-I_{d}\right)=\tau_{c}(\Pi-i C[1-\alpha]-i \mu E) .
$$

Additional taxes on profits $T_{a}$ are levied on the corporate level. The tax base is equal to $F$; the tax rate amounts to $\tau_{a}$.

(7) $\quad T_{a}=\tau_{a} F$

The taxable interest $I_{\text {taxable }}$, dividends $D_{\text {taxable }}$, and capital gains $G_{\text {taxable }}$ are subject to income tax. Additionally, interest that is considered to be a hidden distribution of profits is subject to income tax. The taxable fraction of the hidden distribution of profits is denoted with $B_{\text {taxable }}$. Thus, the burden resulting from income tax is

$$
\begin{aligned}
T_{i}=\tau_{i I} & I_{\text {taxable }}+\tau_{i D}\left(D_{\text {taxable }}+B_{\text {taxable }}\right) \\
& +\tau_{i G} G_{\text {taxable }} .
\end{aligned}
$$

The interest payments that are subject to income tax are identical to the deductible interest payments $I_{d}$ on the corporate level. A fraction $\varepsilon$ of $I_{d}$ is taxable. Hence, the interest payments that are liable to tax amount to

(9) $I_{\text {taxable }}=\varepsilon I_{d}=\varepsilon(i C[1-\alpha]+i \mu E)$.

Only the fraction $\gamma$ of the dividends is subject to income tax

$$
D_{\text {taxable }}=\gamma D
$$

Interest that is interpreted as hidden distribution of profits is treated as dividends and thus likewise taxable by the fraction $\gamma$. The hidden distribution of profits corresponds to non-deductible interest on the corporate level $I_{n d}$. This amount denotes the interest payments that exceed the safe haven.

$$
B_{\text {taxable }}=\gamma B=\gamma I_{n d}=\gamma(i C \alpha-i \mu E) .
$$

Retained earnings $G$ result from the difference between the profit $\Pi$, the corporate tax $T_{c}$ and the additional taxes $T_{a}$, as well as the dividends $D$ and the interest $I$. Thereby, the present value of the capital gains $\theta G$ is taxable at the fraction $\lambda$. In present value terms we obtain

$$
\begin{aligned}
& G_{\text {taxable }}= \lambda \theta\left(\Pi-T_{c}-T_{a}-D-I\right) \\
&=\lambda \theta(\Pi-\underbrace{\tau_{c}[\Pi-i C(1-\alpha)-i \mu E]}_{T_{c}} \\
&-\underbrace{\tau_{a} F}_{T_{a}}-D-\underbrace{i C}_{I}) .
\end{aligned}
$$

Inserting equations (9), (10), (11), and (12) into eq. (8) leads to

$$
\begin{aligned}
& \text { (13) } T_{i}=\tau_{i I} \underbrace{\varepsilon(i C[1-\alpha]+i \mu E)}_{I_{\text {toxable }}} \\
& +\tau_{i D} \underbrace{\gamma(D+i C \alpha-i \mu E)}_{D_{\text {taxable }}+B_{\text {taxable }}} \\
& +\tau_{i G} \lambda \theta\left(\Pi-\tau_{c}[\Pi-i C(1-\alpha)-i \mu E]\right. \\
& \underbrace{\left.-\tau_{a} F-D-i C\right) .}_{G_{\text {taxable }}}
\end{aligned}
$$

The total after-tax income of all investors $\Pi_{\tau}$ is composed of the difference of the gross profit $\Pi$, corporate $\operatorname{tax} T_{c}$, additional taxes on the corporate level $T_{a}$ and income tax $T_{i}$,

（14） $\Pi_{\tau}=\Pi-T_{c}-T_{a}-T_{i}$ 
(15)

$$
\begin{aligned}
\Pi_{\tau}=\Pi & -\underbrace{\tau_{c}(\Pi-i C[1-\alpha]-i \mu E)}_{T_{c}}-\underbrace{\tau_{a} F}_{T_{a}} \\
& -\tau_{i I} \varepsilon(i C[1-\alpha]+i \mu E) \\
& -\tau_{i D} \gamma(D+i C \alpha-i \mu E) \\
& -\tau_{i G} \lambda \theta\left(\Pi-\tau_{c}[\Pi-i C(1-\alpha)\right. \\
\left.-i \mu E]-\tau_{a} F-D-i C\right) & \underbrace{}_{T_{i}}
\end{aligned}
$$

Similar to Miller (1977), to identify the optimal capital structure based on the total after-tax income of all investors, we first have to determine the optimal dividend policy. In a second step we analyze the optimal capital structure. Against the background of the set of equations outlined above, we are able to investigate both an optimal dividend policy and an optimal capital structure under thin capitalization rules in a general capital structure model. Furthermore, analyzing the general setting enables us to draw conclusions about a real-world example, i.e. Italy. This is possible as the Italian thin capitalization rules are fairly simple and thus correspond to those of our general model. Later, we specify the model in more detail to study the implications of modified and simultaneously more complex thin capitalizations rules. Such rules have been introduced in several countries. We take Germany and Belgium as examples of such modified rules and investigate whether the results of the general model are robust under more complex shareholder financing rules.

\section{General thin capitalization rules (Italy)}

\subsection{Critical income tax rate}

In the following, we integrate general thin capitalization rules into our capital structure model. Looking for corresponding real-world rules we find that the rules in section 98 of the Italian Income Tax Code fully comply with our general model. These rules, which are characterized by a small number of attributes, no complicating exceptions, and simple parameters, can be regarded as an illustrating example of our general setting. We implement these rules into our framework to investigate the influence of thin capitalization rules on a general basis on investors' financing decisions (see Appendix A1).

Under section 98 of the Income Tax Code interest on debt capital that a corporation receives from a substantial shareholder, i.e. a shareholder with a shareholding of at least $25 \%$, has to be requalified as hidden distribution of profits if the permitted ratio of debt to equity capital of currently 4:1 is exceeded (Romanelli 2006: 372). Therefore, interest is not considered to be a hidden distribution until the debt of a substantial shareholder exceeds four times their equity share.

Additionally, a regional tax on productive activities (IRAP) is levied on the net value of the production $F$. In line with IRAP interest expenses are not tax-deductible. The tax rate $\tau_{a}$ currently stands at 4.25\% (Romanelli 2006: 367 et seq.).

Dividends and capital gains are $60 \%$ tax-exempt if the shareholder holds either $2 \%$ of voting power or $5 \%$ of the capital of listed companies, or if they hold $20 \%$ of voting power or $25 \%$ of the capital of other companies. Otherwise dividends and capital gains are liable to a final withholding tax of 12.5\% (Romanelli 2006: 377). As we consider substantial shareholders only, a withholding tax is not applicable.

Interest income arising from loans is subject to a withholding tax of $12.5 \%$ that is creditable against the shareholder's income tax liability. A final withholding tax applies to interest on current accounts with bank offices and bonds, but not on loans (Romanelli 2006: 378).

Hence, interest payments, dividends, and capital gains are subject to the same income tax rate $\tau_{i}=\tau_{i I}=\tau_{i D}=\tau_{i G}$.

This reduces the net profit given by equation (15) to

$$
\begin{aligned}
\Pi_{\tau}=\Pi & -\underbrace{\tau_{c}(\Pi-i C[1-\alpha]-i \mu E)}_{T_{c}}-\underbrace{\tau_{a} F}_{T_{a}} \\
& -\tau_{i} \varepsilon(i C[1-\alpha]+i \mu E) \\
& -\tau_{i} \gamma(D+i C \alpha-i \mu E) \\
& -\underbrace{\left.-i \mu E]-\tau_{a} F-D-i C\right)}_{\tau_{i} \lambda \theta\left(\Pi-\tau_{c}[\Pi-i C(1-\alpha)\right.} .
\end{aligned}
$$

To identify the optimal dividend policy, equation (16) has to be differentiated with respect to dividends $D$ and set equal to zero:

$$
\frac{\partial \Pi_{\tau}}{\partial D}=\tau_{i}(\lambda \theta-\gamma)=0 .
$$

We find an investor to be indifferent towards dividend policy only in two cases, namely if their 
marginal income tax rate $\tau_{i}$ amounts to $\tau_{i}=0$ or if the factor $\theta$ amounts to $\theta=\frac{\gamma}{\lambda}$.

The condition $\tau_{i}=0$ is only fulfilled if the investor has no taxable income. Since we assume that the investor obtains interest payments and dividends and/or capital gains, this condition is not fulfilled in our model. Hence, dividend policy is irrelevant only if $\theta=\frac{\gamma}{\lambda}$. Under current legislation we have $\gamma=\lambda$ which leads to $\theta=1$. The time and growth effects from capital gains are cancelled out perfectly and thus $\theta=1$. This is true only if the corporate internal after-tax yield $i\left(1-\tau_{a}-\tau_{a}\right)$ is identical to the after-tax market rate of return the shareholder is able to earn on the capital market $i_{\tau}$. Beyond this setting, dividend policy may not be irrelevant. That said, full retention is always the optimal dividend policy. As long as retained earnings are taxed at a lower effective rate than distributed earnings, full retention of profits always leads to the highest net profit. The same result is achieved by Miller although he does not outline it explicitly. Miller's results are explained by Swoboda (1991: 853) and Laß (1999: 45-46), who find a different result for the German tax code. Both base their assumptions on a split corporate tax scale in connection with the full imputation system. From the authors' point of view the optimal dividend policy depends on the ratio between the personal income tax rate and the corporate tax rate that is applied when profits are retained. If the personal tax rate is significantly lower than the corporate tax rate, a distribution of profits is beneficial to reduce the tax burden from the corporate tax rate applied to retained profits to the lower personal income tax rate ( $\mathrm{Laß} 1999$ : 139-140).

To identify the optimal capital structure based on the optimal dividend policy, equation (16) has to be differentiated considering $D^{*}=0$ with respect to $C$. Rearranging finally leads to the critical income tax rate $\tau_{i}^{*}$ :

$$
\begin{aligned}
\tau_{i}^{*}=[ & \left.\tau_{c}(C[1-\alpha]+\mu E)\right] \\
& \cdot[\varepsilon(C[1-\alpha]+\mu E)+\gamma(C \alpha-\mu E) \\
& \left.+\lambda \theta\left(\tau_{c}[C[1-\alpha]+\mu E]-C\right)\right]^{-1} .
\end{aligned}
$$

Note that the factor $\theta$ is influenced by the after-tax interest rate $i_{\tau}$ and therefore by $\tau_{i}^{*}$. Nevertheless, we assume that $\theta$ is exogenously given. To justify this simplification we have analyzed the interdependency of $\theta$ and $\tau_{i}^{*}$ using an iterative simulation (see Appendix A2). By means of equation (18) the optimal financing decision can be determined for every investor. All investors whose marginal tax rate $\tau_{i}$ equals the critical income tax rate $\tau_{i}^{*}$ are indifferent towards the allocation of debt and equity capital. They are referred to as marginal investors. Investors who have lower tax rates will offer a loan to the corporation, while investors with higher tax rates will offer equity capital (Swoboda 1991: 853). Due to the progressive income tax scale in many countries, e.g., in Italy (Romanelli 2006: 378), a general irrelevance of the financing policy can never be achieved for all taxpayers. Irrelevance can only be achieved for the taxpayers who have marginal tax rates that are identical to the critical income tax rate. Therefore, within this analysis it is only possible to investigate whether or not a Miller equilibrium can be reached for specific taxpayers. Furthermore, the after-tax profit of a firm can never be maximized through mixed financing. Depending on the single parameters, either an equityonly or debt-only financing maximizes after-tax profit, or the means of financing is irrelevant to the after-tax profit of the firm.

\subsection{Sensitivity analysis}

In the following we analyze the implications of a variation of different model parameters. Changes in gross profit $\Pi$ and interest rate $i$ do not influence the critical income tax rate and therefore the financing decision. Hence, we concentrate on the factor $\theta$, the tax rates, the taxable fraction of dividends $\gamma$ and capital gains $\lambda$, the fraction $\alpha$ of debt, the taxable fraction of interest $\varepsilon$, and the permitted ratio of debt to equity $\mu$.

\subsubsection{Time and growth factor for capital gains}

To analyze how the different parameters affect the investor's financing decisions, all variables are assumed to be constant, except for the factor $\theta$. We assume

$$
\begin{gathered}
\tau_{c}=33 \% ; \tau_{i}^{\max }=43 \% ; \\
C=€ 100,000 ; E=€ 1,000 ; \\
\gamma=\lambda=0.4 ; \mu=4 ; \varepsilon=1 ; i=6 \% ; \alpha=1 .
\end{gathered}
$$

Interest payments are fully tax-liable, hence $\varepsilon=1$. Dividends, hidden distributions, and capital gains are subject to a shareholder relief system, i.e. they are all subject to tax at a fraction of $40 \%$ (Romanelli 
2006: 377). Hence, in our model we obtain $\gamma=\lambda=$ 0.4 . As the permitted ratio of debt to equity capital is $4: 1$, in our model the debt-equity parameter $\mu$ is equal to 4 . All interest payments to substantial shareholders are subject to the thin capitalization rules (Romanelli 2006: 372). These regulations imply $\alpha=1$.

Then, the investor receives interest payments of $€ 6,000$ and the safe haven $H$ amounts to $€ 240$. We receive the critical income tax rate:

$$
\tau_{i}^{*}=\frac{79.2}{2,544-2,368 \cdot 32 \theta}
$$

Table 1: Critical income tax rates for various $\theta$ in the general model (e.g., Italy)

\begin{tabular}{lr}
$\theta$ & $\tau_{i}^{*}$ \\
\hline 0.01 & $3.14 \%$ \\
\hline 0.25 & $4.06 \%$ \\
\hline 0.5 & $5.82 \%$ \\
\hline 0.75 & $10.32 \%$ \\
\hline 0.85 & $14.92 \%$ \\
\hline 0.9288 & $23.00 \%$ \\
\hline 0.95 & $26.93 \%$ \\
\hline 0.9964 & $43.00 \%$ \\
\hline 1 & $45.08 \%$ \\
\hline 1.07 & $800.19 \%$ \\
\hline
\end{tabular}

Table 1 shows that the values for the critical income tax rate $\tau_{i}^{*}$ vary between $3.14 \%$ and $800.19 \%$ (see Appendix A2). For $\theta=1.07$ we receive an extremely high critical income tax rate that again indicates that debt financing is always beneficial. If we determine critical income tax rates for higher values of $\theta$ the critical tax rate may change its sign and even become negative. A negative critical income tax rate is not easy to interpret. A closer look at these scenarios clarifies that the basic mechanisms at work do not change. In line with the result for $\theta=1.07$ the resulting (negative) critical tax rate again implies that debt financing is generally favorable.

If $\theta>0.9964$, the critical tax rate is higher than the top tax rate of $43 \%$. In these cases an equilibrium is not possible for the underlying tax system. Then, investors will always prefer to provide a loan instead of equity to the corporation leading to the highest possible net profit $\Pi_{\tau}$.

If $\theta<0.9288$ the critical income tax rate is lower than the minimum tax rate of $23 \%$. In these cases all investors provide equity capital.
Only if $0.9288 \leq \theta \leq 0.9964$ will it depend on the investor's individual income tax rate whether debt or equity financing is optimal. If the personal income tax rate is lower than the critical tax rate, the investor will offer a loan. If it is larger, they will provide equity capital. If the marginal tax rate is equal to the critical income tax rate, the investor is indifferent to either option. In this case we find the so-called Miller equilibrium for this investor. Although at first sight the after-tax internal rate of return falls short of the after-tax external rate of return $(\theta<1)$ shareholders are still willing to provide equity capital as they benefit from preferential capital gains taxation. The time and growth factor $\theta$ does not reflect effects arising from the taxable fraction of capital gains $\lambda<1$. Consequently, providing equity capital can be optimal even for $\theta<1$.

The specific outcome of the factor $\theta$ mainly depends on the ratio of the internal after-tax yield $i\left(1-\tau_{c}-\tau_{a}\right)$ and the after-tax market rate of return $i_{\tau}$. The holding period $n$ exerts only little influence on $\theta$. Assuming that $i\left(1-\tau_{c}-\tau_{a}\right)$ and $i_{\tau}$ are almost equal, leads to $\theta \approx 1$. Then we see that debt financing will be beneficial for most investors.

Income from equity capital, namely dividends and capital gains, is subject to income tax at a fraction of $\gamma=\lambda=0.4$. By contrast, interest income is fully taxed. Interest income amounting to the safe haven is also fully taxable, while the excess is subject to tax to a fraction of $\gamma=0.4$. The lower taxation of dividends and capital gains on the shareholder level compared to interest income usually overcompensates their non-deductibility on the corporate level. Nevertheless, debt capital often is more advantageous than equity capital because income from equity capital, i.e. accumulated capital gains, is usually higher than interest income. Differentiating equation (19) with respect to $\theta$ we obtain the derivative $\frac{\partial \tau_{i}^{*}}{\partial \theta}$ which is always positive:

(20) $\frac{\partial \tau_{i}^{*}}{\partial \theta}=\frac{187,571}{(2,544-2,268 \theta)^{2}}>0$.

An increase in $\theta$ causes a higher taxation of capital gains and consequently a higher taxation of equity capital. Hence, the relative advantage of debt capital increases compared to equity capital. 


\subsubsection{Tax rates}

A rise in the corporate tax rate has two counteracting effects. On the one hand, the tax advantage of debt capital (tax shield) at the corporate level increases and so does the relative advantage of debt capital (see Buettner, Overesch, Schreiber, and Wamser 2006: 11, who come to the same conclusion in the case of financing a German corporation owned by foreign shareholders). Equity capital is more burdened by a higher tax rate, as dividends are not tax-deductible on the corporate level. On the other hand, the factor $\theta$ decreases because the corporate internal after-tax yield $i\left(1-\tau_{c}-\tau_{a}\right)$ declines. A decrease in $\theta$ leads, as shown above, to an increasing relative advantage of equity capital. In Italy the tax-shield effect always dominates, causing an overall increasing advantage of debt capital. Mathematically this result becomes obvious in that the derivative $\frac{\partial \tau_{i}^{*}}{\partial \tau_{c}}$ is always positive.

A change in the corporate tax rate has a relatively low impact on the investor's financing decision. Assuming a holding period of, e.g., $n=10$ years, a decrease in the tax rate from $33 \%$ to $10 \%$ leads to changes in the critical income tax rate of 9 percentage points. By contrast, an increase in the corporate tax rate to $50 \%$ raises the critical tax rates by 6 percentage points.

Varying the IRAP tax rate has no tax-shield effect because interest payments are not deductible under this tax. A change in the IRAP tax rate only amends the factor $\theta$ such that the relative advantage of equity capital increases. The derivative $\frac{\partial \tau_{i}^{*}}{\partial \tau_{a}}$ is always negative. E.g., assuming a holding period of 10 years a rise in the tax rate from currently $4.25 \%$ to $10 \%$ decreases the critical income tax rate from $12.57 \%$ to $3.11 \%$.

\subsubsection{Taxable fraction of dividends and capital gains}

In Italy dividends and capital gains are subject to tax at the same fraction $\gamma=\lambda=0.4$. In this section we analyze the effects of an isolated change in the taxable fraction of dividends $\gamma$ and the taxable fraction of capital gains $\lambda$, respectively. We also investigate the influence of a change in the taxable fraction of both dividends and capital gains. A rise in the taxable fraction of dividends $\gamma$ leads to a decrease in critical income tax rate and therefore an increase in the relative advantage of equity capital:

(21) $\frac{\partial \tau_{i}^{*}}{\partial \gamma}=\frac{-1.27 \cdot 10^{8}}{(4,000+96,000 \gamma-39,472 \theta)^{2}}<0$.

This result, which seems surprising at first glance, can be explained as follows: we have already shown that companies do not distribute profits in this model framework. Instead, payments for equity capital are always realized as capital gains. If the taxable fraction of dividends is increased, this leads to a higher taxation of interest payments from thin capitalization that have to be requalified as hidden distribution of profits. Therefore, an increase in $\gamma$ implies a higher taxation of debt capital.

Correspondingly, an isolated increase in the taxable fraction of capital gains $\lambda$ leads to a higher taxation of equity capital and an increasing relative advantage of debt capital. The critical income tax rate rises when increasing $\lambda$ :

$$
\frac{\partial \tau_{i}^{*}}{\partial \lambda}=\frac{1.30 \cdot 10^{8} \theta}{(42,400-98,680 \lambda \theta)^{2}}>0 .
$$

Focussing on a change in both the taxable fraction of dividends and capital gains $(\gamma=\lambda)$, we obtain

$$
\text { (23) } \frac{\partial \tau_{i}^{*}}{\partial \gamma}=\frac{-1.27 \cdot 10^{8}+1.3 \cdot 10^{8} \theta}{(4,000+1,000 \gamma[9.6-9.9 \theta])^{2}} \gtreqless 0 \text {. }
$$

The derivative is positive or negative depending on the factor $\theta$. Figure 1 shows that the derivative $\frac{\partial \tau_{i}^{*}}{\partial \gamma}$ is zero if $\theta=0.9728$. A negative derivative arises if $\theta$ is smaller than 0.9728 . Then, equity capital becomes more attractive. The effect from higher taxation of dividends that leads to an increased advantage of equity capital is higher than the effect from higher taxation of capital gains that causes an increased advantage of debt capital.

The derivative $\frac{\partial \tau_{i}^{*}}{\partial \gamma}$ is positive if $\theta>0.9728$. In these cases the relative advantage of debt capital increases. The effect of the higher taxation of capital gains overcompensates the effect of the higher dividend taxation because a high value of the factor $\theta$ additionally causes a higher taxation of equity capital.

\subsubsection{Fraction of considered debt}

At present all interest payments to substantial shareholders are subject to Italian thin capitalization rules. Therefore, the parameter $\alpha$ has been set equal to 1 . Lowering the fraction $\alpha$ leads to a rise in the critical income tax rate and hence an increas- 


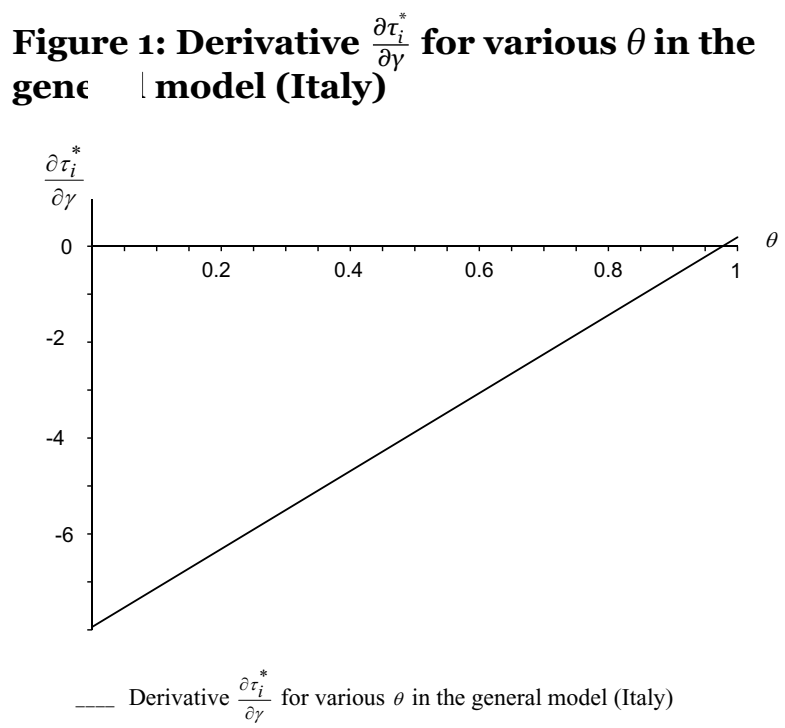

ing relative advantage of debt capital compared to equity capital:

$$
\begin{aligned}
\frac{\partial \tau_{i}^{*}}{\partial \alpha}=[ & \left.-5.4 \cdot 10^{9}+1.3 \cdot 10^{9} \theta\right] \\
& {[102,400-60,000 \alpha-26,272 \theta} \\
& -13,200 \theta \alpha]^{-2}<0
\end{aligned}
$$

This effect is true because the interest payments which are subject to thin capitalization and requalified as hidden distributions of profit decrease, as does the corporate tax. A reduction in the fraction of considered debt $\alpha$ has a relatively high influence on the critical income tax rate. A reduction from $\alpha=1$ to $\alpha=0.01$ would lead to a rise in the critical income tax rate of up to 32 percentage points.

\subsubsection{Other model parameters}

Assuming a decrease in the taxable fraction of interest of $\varepsilon=1$ to values with $\varepsilon<1$, we obtain a rise in the critical income tax rate. The derivative $\frac{\partial \tau_{i}^{*}}{\partial \varepsilon}$ is always negative. This effect in turn increases the relative advantage of debt capital because a lower taxable fraction of interest implies a lower taxation of debt capital.

The influence of the permitted ratio of debt to equity capital $\mu$ and of the amount of equity capital $E$ can be analyzed simultaneously since both variables only affect the safe haven $H=i \mu E$. The multiple $\mu E$ denotes the maximum amount of debt capital that a substantial shareholder can provide to the corporation while tapping the full potential of the safe haven. An increasing multiple $\mu E$ and consequently an increasing safe haven $H$ leads to a decreasing corporate tax because the amount of deductible interest payments increases. At the same time the income tax increases because the additionally deductible interest payments are taxed to the full amount whereas hidden distributions are only subject to tax at the fraction $\gamma=0.4$. The effect on the corporate level always dominates. Therefore, the relative advantage of debt capital compared to equity capital increases with rising $\mu E$. If the permitted ratio of debt to equity capital $\mu$ is increased, e.g., from 4 to 20 , debt capital may be twenty times the equity capital contributed by one shareholder while a change in the critical income tax rate amounts to a maximum of 17 percentage points.

\subsubsection{Results}

We are able to show that except for the gross profit $\Pi$ and the interest rate $i$ all model parameters have an influence on the investors' financing decisions. Whereas the influence of the corporate tax rate, the IRAP tax rate, the taxable fraction of dividends, capital gains, and interest is low, the factor $\theta$, the fraction of considered debt, and the multiple $\mu E$ exert a high influence on financing decisions. As $\theta$ is mainly driven by the relation of the corporate tax rate to the individual income tax rate, obviously the tax rate difference determines the financing decision significantly if capital gains are taxable. A closer look clarifies that $\theta$ can significantly change the critical income tax rate whereas a change in the corporate tax rate cannot. E.g., if the corporate tax rate rises, two partial effects on the critical income tax can occur. One effect is an increase in the critical income tax rate because of an increasing tax shield from debt financing. Simultaneously the critical income tax rate is reduced because of a decrease in the factor $\theta$. Consequently, the overall effect of a rise in the corporate tax rate on the critical income tax rate determined by these two opposing partial effects is small. Only the influence of the taxable fraction of dividends seems counterintuitive as a rise in the taxable fraction of dividends $\gamma$ causes a rise in the attractiveness of equity capital.

Given the Italian tax policy with capital gains taxation, the underlying thin capitalization rule with a given permitted debt-to-equity ratio is typically not irrelevant with respect to capital structure de- 
cisions. Here, financing decisions mainly depend on the corporate-income tax rate differential and therefore the parameter $\theta$. Consequently, the tax scale is an important driver of the financing decision. The treasury needs to know the distribution of investors across tax classes to forecast whether it is likely that the majority of investors will tend to provide debt instead of equity capital under the thin capitalization rules.

We find that changes in some model parameters have a higher impact on the critical income tax rates than changes in other parameters. This difference in sensitivity is due to the functional form of the net profit.

Several countries have implemented more complex thin capitalizations rules. Against this background and the results mentioned above, it is worthwhile to find out whether we obtain corresponding or deviating results under more specified rules and to what extent the characteristics of the underlying tax system determine the effects. We take Germany and Belgium as examples and perform an analysis in the following sections.

\section{Complex thin capitalization rules (Germany)}

\subsection{Critical income tax rate}

In this section we integrate the German thin capitalization rules according to section 8a of the German Corporate Tax Code as amended by the Korb II tax reform act (section 8a of the German Corporate Tax Code as amended by the Korb II tax reform act dated Dec. 22, 2003, BGBl. I 2003: 2841 et seq.) into the model. This rule that was introduced in 2004 has been reformed by the German business tax reform act 2008 where it was substituted by an interest barrier (section $4 \mathrm{~h}$ of the Income Tax Code and section 8a of the German Corporate Tax Code as amended by the German Business Reform dated Aug. 14, 2007, BGBl. I 2007: 1913 et seq., 1927 et seq.). Section $8 \mathrm{a}$ is an example of a complex thin capitalization rule characterized by a given permitted debt-equity capital ratio.

Under this debt-equity-ratio-based thin capitalization rule, interest on debt capital that a corporation receives from a shareholder with a shareholding of more than $25 \%$, under certain circumstances, has to be requalified as a hidden distribution of profits. This regulation only holds if the shareholder's capital commitment is long term and if the tax allowance of $€ 250,000$ of interest on debt is exceeded. The permitted ratio of debt to equity capital is 1.5:1 (section 8a para 1 no. 2 of the German Corporate Tax Code). As only interest payments for long-term debt are subject to this regulation, the parameter $\alpha$ represents the fraction of long-term debt in Germany. The tax allowance (section 8a para 1 of the German Corporate Tax Code) of $€ 250,000$ of interest is assumed to be exceeded.

In addition to the corporate tax the German local business tax has to be taken into account on the corporate level. This tax treats equity and debt differently. To integrate effects of the local business tax into the model further assumptions are necessary. Corporate income as defined in the German Corporate Tax Code is the basis for determining the local business tax base $F$ (section 7 sentence 1 of the German Local Business Tax Code). Since the local business tax itself is an operating expense, it is deductible from its own tax base. We consider this deductibility by introducing an effective local business tax rate $\tau_{a}$ (see Appendix A1). Furthermore, amongst the various tax base adjustments listed in section 8 of the German Local Business Tax Code, only the addition of $50 \%$ of the interest payments for long-term debt (section 8 no. 1 of the German Local Business Tax Code) is considered in the model. Splitting debt into long-term and short-term debt indirectly introduces a time dimension into the model. Although we develop a static model that by definition does not account for timing effects, a differentiation between long-term and short-term debt is necessary to distinguish between different types of interest for local business tax and thin capitalization purposes. Nevertheless, the model remains static. Reductions according to section 9 of the German Local Business Tax Code are not considered at all. The fraction of the interest that is long-term debt (section 8 no. 1 of the German Local Business Tax Code) is denoted by $\alpha \in(0,1]$. If $\alpha=0$, section 8 a of the German Corporate Tax Code does not apply. Hence, the addition of interest payments for long-term debt is equal to $0.5 I_{d}$.

Dividends, hidden distributions, and capital gains are subject to the same income tax rate $\tau_{i}=\tau_{i I}=$ $\tau_{i D}=\tau_{i G}$.

Taking into account the local business tax, the net 
profit $\Pi_{\tau}$ is equal to (see Maßbaum and Sureth 2008 for a more detailed analysis of the influence of the German section 8a thin capitalization rule on capital structure decisions)

$$
\begin{aligned}
\Pi_{\tau}=\underbrace{\Pi}_{T_{a}} \underbrace{-\tau_{a}[\Pi-i C(1-\alpha)-0.5 i \mu E]}_{T_{c}} \\
-\underbrace{}_{T_{c}[\Pi-i C(1-\alpha)-i \mu E}-\tau_{a}(\Pi-i C(1-\alpha)-0.5 i \mu E)] \\
-\tau_{i} \varepsilon[i C(1-\alpha)+i \mu E] \\
-\tau_{i} \gamma[D+i C \alpha-i \mu E] \\
-\tau_{i} \lambda \theta\left[\Pi-\tau_{a}(\Pi-i C(1-\alpha)\right. \\
-0.5 i \mu E) \\
-\tau_{c}(\Pi-i C(1-\alpha)-i \mu E \\
\left.-\tau_{a}[\Pi-i D C(1-\alpha)-0.5 i \mu E]\right) \\
\quad \underbrace{-D-i C] .}
\end{aligned}
$$

To identify the optimal dividend policy, equation (25) has to be differentiated with respect to $D$ :

$$
\frac{\partial \Pi_{\tau}}{\partial D}=\tau_{i}(\lambda \theta-\gamma)=0
$$

We see that the investor is only indifferent towards dividend policy in two cases, namely if the income tax rate $\tau_{i}=0$ or if the factor $\theta=\frac{\gamma}{\lambda}$. This is the same result we obtained for Italy (see section 3.1 and Appendix A2). Beyond these cases full retention is always the optimal dividend policy.

To obtain the optimal capital structure equation (25) has to be differentiated with respect to $D^{*}=0$ to $C$ and it has to be set to zero. As a result we get the critical income tax rate $\tau_{i}^{*}$,

$$
\begin{aligned}
& \tau_{i}^{*}=\left[\tau_{a}[C(1-\alpha)+0.5 \mu E]\right. \\
& +\tau_{c}[C(1-\alpha)+\mu E \\
& \left.\left.-\tau_{a}(C(1-\alpha)+0.5 \mu E)\right]\right] \text {. } \\
& {[\varepsilon[C(1-\alpha)+\mu E]+\gamma(C \alpha-\mu E)}
\end{aligned}
$$

$$
\begin{aligned}
& +\lambda \theta\left(\tau_{a}[C(1-\alpha)+0.5 \mu E]\right. \\
& +\tau_{c}[C(1-\alpha)+\mu E \\
& \left.\left.\left.-\tau_{a}(C(1-\alpha)+0.5 \mu E)\right]-C\right)\right]^{-1} .
\end{aligned}
$$

\subsection{Sensitivity analysis}

As in the general model, the gross profit $\Pi$ and the interest rate $i$ have no influence on the critical income tax rate and therefore on investors' financing decisions. The other model parameters exert an influence on the critical income tax rate. The degree of sensitivity of the critical tax rate towards variation in the different parameters varies significantly. Therefore, we highlight the most important value drivers.

\subsubsection{Time and growth factor for capital gains}

To analyze the influence of the factor $\theta$ all other model parameters remain constant. We assume

$$
\begin{gathered}
\tau_{c}=25 \% ; \tau_{i}^{\max }=42 \% ; \tau_{a}=16.28 \% ; \\
C=€ 100,000 ; E=€ 1,000 ; \\
\gamma=\lambda=0.5 ; \mu=1.5 ; \varepsilon=1 ; i=6 \% ; \alpha=1 .
\end{gathered}
$$

We obtain the effective local business tax rate $\tau_{a}$ by considering the average collection rate of $h=389 \%$ (Federal Statistical Office 2007) and a taxable business value of $m=5 \%$. As the permitted ratio of debt to equity capital is $1.5: 1$, the parameter $\mu$ is equal to 1.5 . The fraction of long-term debt is represented by the parameter $\alpha$. Under income tax law earned interest is fully taxable (section 20 para 1 no. 7 of the Income Tax Code), therefore $\varepsilon$ is equal to 1 . The distributed profits $D$, hidden distributions, and capital gains are subject to the half-income system and thus only $50 \%$ of this type of capital income is taxable, i.e. $\gamma=\lambda=$ 0.5 (section 20 para 1 no. 1 in conjunction with section 3 no. 40 d) of the Income Tax Code, see Appendix A1).

The investor receives total interest $I$ of $€ 6,000$. Within the safe haven interest of $I_{d}=H=€ 90$ is tax-deductible at the corporate level.

Inserting the assumptions the critical income tax rate as a function of $\theta$ is

$$
\tau_{i}^{*}=\frac{466.575}{50,750-49,766.71 \theta}
$$


Table 2 shows the critical income tax rates for different values of the factor $\theta$ (see Appendix A2).

Table 2: Critical income tax rates for various $\theta$ in Germany

\begin{tabular}{lr}
$\theta$ & $\tau_{i}^{*}$ \\
\hline 0.01 & $0.93 \%$ \\
\hline 0.25 & $1.22 \%$ \\
\hline 0.5 & $1.80 \%$ \\
\hline 0.75 & $3.48 \%$ \\
\hline 0.95725 & $15.00 \%$ \\
\hline 0.99845 & $42.00 \%$ \\
\hline 1 & $47.45 \%$ \\
\hline 1.015 & $197.04 \%$ \\
\hline
\end{tabular}

We see that the values for the critical income tax rate vary between $0.93 \%$ and $197.04 \%$. If the factor $\theta$ is higher than 0.99845 , the critical income tax rate is higher than the top tax rate of $42 \%$. In these cases, debt capital is advantageous for all shareholders. If $\theta$ is lower than 0.95725 , the critical income tax rate is lower than the minimum income tax rate of $15 \%$ and all investors will provide equity capital. Only if $0.95725 \leq \theta \leq 0.99845$, it depends on the investors' marginal tax rate as to whether debt or equity capital is favorable (section 3.2.1).

For $\theta=1.015$ we receive an extremely high critical income tax rate that again indicates that debt financing is always beneficial. If we determine critical income tax rates for higher values of $\theta$ the critical tax rate may change its sign and even become negative (see section 3.2.1 for an interpretation of these effects).

We obtain the derivative $\frac{\partial \tau_{i}^{*}}{\partial \theta}$ by differentiating equation (27) with respect to $\theta$ and inserting the assumptions. As in the general model this derivative is also positive in Germany. Therefore, an increasing $\theta$ leads to an increasing relative advantage of debt capital compared to equity capital (section 3.2.1).

$$
\frac{\partial \tau_{i}^{*}}{\partial \theta}=\frac{23,220}{(50,750-49,766.71 \theta)^{2}}>0
$$

In Figure 2 we compare the German and Italian critical income tax rates. We see that the German tax rates are usually lower than the Italian tax rates. Only if $\theta$ is higher than 0.9986 are the German tax rates higher than the Italian. This implies that in Germany equity capital is usually more attractive in comparison to debt capital than in Italy. Only if $\theta>0.9986$ is debt capital more attractive in Germany than in Italy.

\section{Figure 2: Critical income tax rates for various $\theta$ in Germany and Italy}

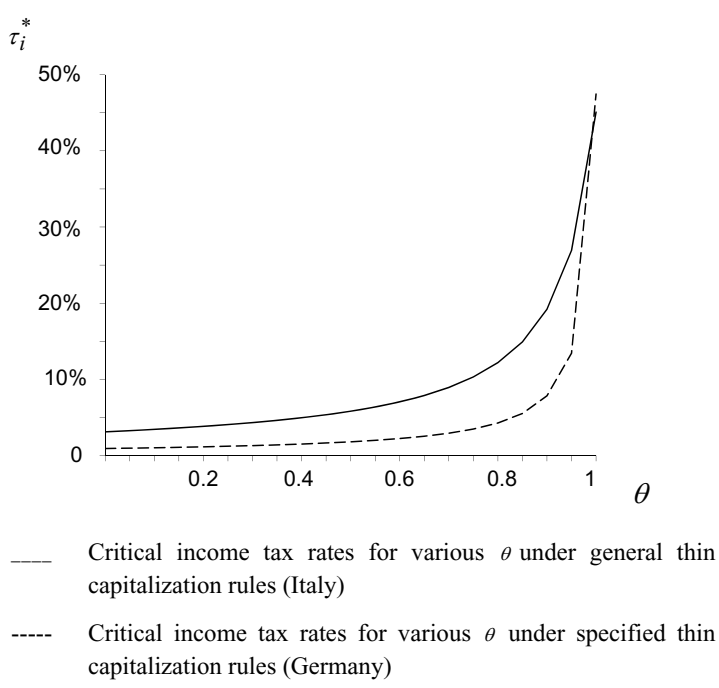

Debt capital is usually less attractive in Germany than in Italy, because debt capital is more severely burdened due to the addition of a fraction of the interest payments for long-term debt for local business tax purposes and the lower permitted ratio of debt to equity capital. If the factor $\theta$ increases this implies a higher effective taxation of capital gains and consequently a reduced attractiveness of equity capital in both Italy and Germany. As the nominal taxation of capital gains $\lambda$ is lower in Italy than in Germany, equity capital becomes less unattractive in Italy than in Germany.

\subsubsection{Tax rates}

A rise in the corporate tax rate $\tau_{c}$ incurs an increasing critical income tax rate and therefore an increasing advantage of debt capital over equity capital. This result is in line with the result we obtained for Italy (section 3.2.2).

By contrast, an increase in the local business tax rate $\tau_{a}$ decreases the critical income tax rate and therefore leads to an increasing relative tax advantage of equity capital. In this case the tax shield effect invoking a higher advantage of debt capital is lower than the opposing effect caused by the negative impact of rising $\tau_{a}$ on $\theta$, because in Germany the fraction of interest payments that is 
tax-deductible with respect to the local business tax is lower than for corporate tax purposes.

Assuming a holding period of $n=10$ years exemplifies that a decrease in the corporate tax rate from $25 \%$ to $10 \%$ leads to a reduction in the critical income tax rate of only 0.7 percentage points, a corresponding increase in the corporate tax rate to an increase of only 0.5 percentage points. Similarly, changes in the local business tax rate also only have a low influence on the critical income tax rate. Assuming a decrease in the local business tax to $10 \%$ raises the critical income tax rate by 0.2 percentage points, an increase to $30 \%$ results in a change in the critical income tax rate of 0.3 percentage points.

\subsubsection{Taxable fraction of dividends and capital gains}

As in Italy, in Germany dividends and capital gains are subject to the same taxable fraction $\gamma=\lambda$.

An exclusive rise in the taxable fraction of dividends $\gamma$, as in Italy, lowers the critical income tax rate and therefore increases the relative advantage of equity capital (section 3.2.3):

(30) $\frac{\partial \tau_{i}^{*}}{\partial \gamma}=\frac{-4.60 \cdot 10^{7}}{(1,500+98,500 \gamma-49,767 \theta)^{2}}<0$.

Analyzing c.p. an increased capital gains taxation, i.e. an increase in $\lambda$, we obtain the following derivative that is, as in Italy, always positive (section 3.2.3):

$$
\frac{\partial \tau_{i}^{*}}{\partial \lambda}=\frac{4.64 \cdot 10^{7} \theta}{(50,750-99,533 \lambda \theta)^{2}}>0
$$

A change in the taxable fraction of both dividends and capital gains $\gamma$ leads to a derivative that is, depending on the factor $\theta$, positive, negative or zero:

$$
\frac{\partial \tau_{i}^{*}}{\partial \gamma}=\frac{-4.6 \cdot 10^{7}+4.64 \cdot 10^{7} \theta}{(1,500+98,500 \gamma-99,533 \gamma \theta)^{2}} \gtreqless 0 .
$$

The derivative is positive if $\theta$ is higher than 0.9896 , negative if $\theta$ is lower than 0.9896 , and equal to zero if $\theta$ is 0.9896 . For Italy we obtain a similar value of $\theta=0.9728$. Hence, the integration of the local business tax and the different values of the model parameters do not substantially affect the influence of the taxable fraction of dividends and capital gains on the critical income tax rate and therefore on investors' financing decisions.

\subsubsection{Fraction of considered debt}

Assuming a change in the fraction of considered debt $\alpha$ we obtain the following derivative:

$$
\text { (33) } \begin{aligned}
\frac{\partial \tau_{i}^{*}}{\partial \alpha}=[ & \left.-1.86508 \cdot 10^{9}+1.8605 \cdot 10^{9} \theta\right] \\
& {[100,750-50,000 \alpha} \\
& \quad-31,162 \theta-18,605 \alpha \theta]^{-2}<0 .
\end{aligned}
$$

In Germany only long-term debt capital is subject to the thin capitalization rules of section $8 \mathrm{a}$ of the German Corporate Tax Code. Therefore, the investor can influence the parameter $\alpha$ by providing long-term or short-term debt, respectively. Lowering the fraction of long-term debt leads to an increasing relative advantage of debt capital compared to equity capital.

\subsubsection{Other model parameters}

Considering changes in the taxable fraction of interest $\varepsilon$ and the multiple of the permitted ratio of debt to equity capital and the amount of equity capital $\mu E$ we obtain the same influences as in Italy (section 3.2.5).

A decrease in the taxable fraction $\varepsilon$ of interest leads to an increasing relative advantage of debt capital. The first derivative $\frac{\partial \tau_{i}^{*}}{\partial \varepsilon}$ is always negative. Considering a rise in the multiple $\mu E$ we obtain a higher relative attractiveness of debt capital.

\subsubsection{Results}

To study the influence of the German thin capitalization rules on financing decisions we had to extend the general model to include the local business tax. This tax is quite different from the Italian IRAP as the resulting tax burden depends on the investor's financing decision. In spite of the introduction of this tax we obtain very similar results for both Germany and Italy. We can show that in both countries the gross profit and the interest rate do not influence the investors' financing decisions, whereas changes in the other model parameters exert the same influences in both countries. A change in the German local business tax rate has a 
less severe influence on the critical income tax rate than a change in the Italian IRAP tax rate because interest payments are not tax-deductible under an IRAP. For this reason a variation of the IRAP tax rate does not invoke a tax shield.

\section{Complex thin capitalization rules (Belgium)}

After having considered the Italian and German thin capitalization rules we now analyze the influence of another debt-equity-ratio-based rule, namely the Belgian regulation on shareholders' financing decisions which was introduced in 1997. In Belgium interest payments are requalified as hidden distribution of profits and therefore treated as dividends if the permitted ratio of debt to equity capital of $1: 1$ is exceeded. The Belgian thin capitalization rules are applicable to all shareholders. A minimum shareholding is not necessary. The thin capitalization rules include all loans that a shareholder provides the corporation (Offermanns 2006: 73).

A notional interest deduction for equity capital is granted to corporations. Thus, the Belgian system applies an Allowance for Corporate Equity (ACE) device which was intended to account for the distinction of interest payments to external providers of capital compared to those from associated members of corporations. Introducing an ACE was regarded as a step towards a more neutral tax system and towards improving Belgium as an investment location (Gerard 2006: 156). The deduction is based on the book value of the company's equity. It is calculated by multiplying the equity by a fixed percentage determined by the government. For 2007 the percentage is equal to $i_{n}=3.442 \%$. The notional interest rate is set by the government on the basis of the interest rate on 10-year government bonds (Cowley, Gutiérrez, Kesti, and Soo 2008: 91).

In contrast to Italy and Germany, additional taxes $\tau_{a}$ are not levied on the corporate level.

Dividends and interest income are subject to a withholding tax of $\tau_{i D}=25 \%$ and $\tau_{i I}=15 \%$ respectively (Offermanns 2006: 78). Alternatively, the investor can choose to include dividends and interest income into their individual assessment if this leads to a lower taxation. In this case $\tau_{i D}=\tau_{i I}$. In the following we analyze both cases, the scenario with withholding tax in section 5.1 and with individual assessment in section 5.2. We only consider the case that the investor chooses to include both interest and dividends into assessment. For reasons of transparency we do not model mixed scenarios.

Capital gains are not subject to tax, therefore $\tau_{i G}=$ o (Offermanns 2006: 76). In a first step we assume that capital gains are also subject to the withholding tax of $25 \%$. This assumption enables us to isolate the effects of the introduction of a capital gains tax. Hence, we assume that $\tau_{i G}=$ $25 \%$.

\subsection{Withholding tax \\ 5.1.1 Critical income tax rate}

Considering the withholding tax we assume

$$
\tau_{i D}=\tau_{i G}=25 \% ; \tau_{i I}=15 \% .
$$

We obtain the following net profit $\Pi_{\tau}$

$$
\begin{aligned}
& \Pi_{\tau}=\Pi-\underbrace{\tau_{c}\left(\Pi-i C(1-\alpha)-i \mu E-i_{n} E\right)}_{T_{c}} \\
& -0.15 \varepsilon(i C(1-\alpha)+i \mu E) \\
& -0.25 \gamma[D+i C \alpha-i \mu E] \\
& \text { - } 0.25 \lambda \theta\left(\Pi-\tau_{c}[\Pi-i C(1-\alpha)\right. \\
& \underbrace{\left.\left.-i \mu E-i_{n} E\right]-D-i C\right) .}_{T_{i}}
\end{aligned}
$$

By differentiating equation (34) with respect to the dividends $D$ the following dividend policy turns out to be optimal:

（35) $\frac{\partial \Pi_{\tau}}{\partial D}=\lambda \theta-\gamma=0$.

The investor is only indifferent towards the dividend policy if $\lambda \theta=\gamma$. As capital gains are not subject to tax in Belgium at present, we receive $\lambda \theta=0$. The condition only holds if $\gamma=0$, namely if dividends are not subject to tax. Since dividends are fully taxable in Belgium, hence $\gamma=1$ and indifference to the dividend policy is not possible at present. Instead full retention is always the optimal dividend policy. Because capital gains are not subject to tax whereas dividends are, full retention always leads to the highest net profit. 
Taking account of the withholding tax the income tax rate is no longer a function of the tax base but exogenously given, because $\tau_{i I}=15 \%$ and $\tau_{i D}=\tau_{i G}=25 \%$. Thus, a critical income tax rate $\tau_{i}^{*}$ cannot be determined. The optimal capital structure decision does not depend on the investor's marginal income tax rate but only on the values of the other model parameters.

\subsubsection{Sensitivity analysis}

In the following we analyze the influence of selected model parameters on the investor's financing decisions.

For the basic scenario we assume

$$
\begin{gathered}
\tau_{c}=33 \% ; \tau_{i}^{\max }=50 \% ; i_{n}=3.442 \% ; i=6 \% ; \\
C=€ 100,000 ; E=€ 1,000 ; \Pi=€ 10,000 ; \\
\gamma=1 ; \lambda=0 ; \mu=1 ; \varepsilon=1 ; \alpha=1 .
\end{gathered}
$$

Corporations with a tax base up to $€ 322,500$ are subject to a progressive tax scale. Corporations with a higher tax base are subject to a tax rate of 33\% (Offermanns 2006: 65, see Appendix A1). We assume that the tax base exceeds $€ 322,500$. The shareholders are subject to a progressive income tax scale. The top tax rate $\tau_{i}^{\max }$ to the amount of $50 \%$ is imposed if the tax base exceeds $€ 31,700$ (Offermanns 2006: 77, see Appendix A1).

Dividends, interest payments, and hidden distributions are subject to income tax to the full amount, hence $\varepsilon=\gamma=1$. Capital gains are tax-exempt, hence $\lambda=0$. The thin capitalization rules are applicable for all loans provided by shareholders, i.e. $\alpha=1$. The permitted ratio of debt capital to equity capital is $1: 1$, i.e. $\mu=1$.

Inserting the assumptions into equation (34) we obtain a net profit of $€ 6,711$ in the case of equity financing and a net profit of $€ 5,237$ in the case of debt financing. The investors will therefore decide to provide equity capital instead of debt capital. Payments for equity financing are only taxed with corporate tax at $33 \%$. In line with notional interest deduction, a notional amount of interest can be deducted from the corporate tax base. The payments for equity are not taxed on the shareholder level because full retention is the optimal dividend policy and capital gains are tax-exempt.

Interest payments are tax-deductible on the corporate level up to the safe haven. Those that exceed the safe haven are non-deductible and therefore subject to corporate tax of $33 \%$. On the share- holder level interest payments up to the safe haven are subject to the withholding tax rate of $15 \%$ while the excess is subject to the withholding tax of $25 \%$. Consequently, interest payments amounting to the safe haven are possibly taxed lower than payments for equity capital. But interest payments that exceed the safe haven are taxed considerably higher (33\% corporate tax plus $25 \%$ withholding tax).

Since we assume the safe haven always to be exceeded and since Belgium has a very low safe haven, interest payments are always taxed higher than capital gains.

As in Italy and Germany, a variation of the gross profit and the interest rate has no influence on the financing decisions. The same is true for changes in the notional interest rate.

As long as capital gains are not subject to tax, i.e. $\lambda=0$, a change in the time and growth factor for capital gains $\theta$ has no influence on the investor's financing decisions. If capital gains are not taxexempt, i.e. $\lambda>0$, a variation of $\theta$ influences the investor's financing decisions. Since capital gains are subject to tax at $\lambda \theta$, a change in the factor $\theta$ has the same influence on the financing decisions as a change in the taxable fraction $\lambda$.

As in Italy and Germany, an increasing corporate tax rate leads basically to an increasing relative advantage of debt capital compared to equity capital (section 3.2.2). The increasing relative advantage of debt capital is very low, due to the notional interest deduction for payments for equity capital. As $\tau_{c} \in[0,1]$ an irrelevance of the financing decision or even an advantage of debt capital cannot occur in Belgium.

Investigating the effects of an isolated decreasing taxable fraction of dividends we find a rising attractiveness of debt capital (section 3.2.3). The investor is only indifferent towards debt and equity capital if $\gamma=-0.00038$. As $\gamma \in[0,1]$ a change in the taxation of dividends does not change the financing decision. Equity capital is always advantageous.

The introduction of a capital gains taxation, while assuming that dividends are subject to tax to the full amount, i.e. $\gamma=1$, leads to an increased relative advantage of debt capital (section 3.2.3). Nevertheless, debt capital would become advantageous only for negative $\lambda$-values. As $\lambda \in[0,1]$, equity capital is always advantageous.

In Italy and Germany, a change in the taxable fraction of both dividends and capital gains $(\gamma=$ $\lambda$ ) leads, depending on the value of the factor 
$\theta$, to a change in the relative advantage of debt over equity capital (section 3.2.3). In Belgium, a change in these parameters does not change the shareholder's financing decision. A decreasing $\gamma$ and $\lambda$ leads to an increasing relative advantage of debt capital, but an advantage of debt capital towards equity capital can only occur for negative values of $\gamma$ and $\lambda$.

A decrease in the fraction of considered debt from presently $\alpha=1$ to $\alpha<1$ reduces the drawback of debt over equity caused by the thin capitalization rule (section 3.2.5). If $\alpha=0.4242$ the investor is indifferent towards debt and equity financing. If the tax law is modified accordingly, which is rather unlikely, the net profit is identical for both debt and equity financing. Only if the fraction of considered debt is lower than 0.4242 do we find an advantage of debt financing because then, net profit increases with an increasing gearing rate.

A tax reform changing $\alpha$ directly to alleviate interest deduction restrictions is very unlikely to be discussed. It is more likely that thin capitalization rules are alleviated by restricting their application to long-term debt as is the case in Germany, for instance. If the Belgian government only referred to interest payments on long-term debt in their modified thin capitalization rules, a fraction of long-term debt of $42.42 \%$ would be equal to a fraction of $\alpha=0.4242$. In this case, the investor can benefit from debt financing if their interest on long-term debt does not exceed $42.42 \%$ of the interest on short-term debt.

Given that interest payments are subject to tax to the full amount, namely $\varepsilon=1$, a decrease in the taxable fraction $\varepsilon$ leads to an increasing relative advantage of debt capital. Concentrating on the influence of a change in $\varepsilon$ on the financing decision, we find that the investor is indifferent towards debt and equity financing if $\varepsilon=-164$. Since $\varepsilon \in[0,1]$ in fact an indifference cannot arise. Instead, the investor will always prefer to provide equity capital. In contrast to Italy and Germany a change in the permitted ratio of debt to equity capital $\mu$ and in the amount of equity capital $E$ cannot be analyzed jointly, because a change in equity capital not only influences the safe haven $H=i \mu E$, but also the notional interest deduction $i_{n} E$. Assuming an increasing $\mu$ or an increasing $E$ we obtain a rising relative advantage of debt capital (section 3.2.5). Capital structure irrelevance arises if $\mu$ is increased to 58 or if debt capital is increased to 104,000 . Debt capital will be preferred if $\mu>58$ or $E>104,000$.

\subsubsection{Results}

Considering the Belgian thin capitalization rules in the light of the withholding tax option, the financing decision, unlike in Italy and Germany, does not depend on the investor's marginal income tax rate but only on the other model parameters. Varying different model parameters leads to similar financing decision patterns as under the Italiantype and German-type rules. Whereas in Italy and Germany capital structure irrelevance is generally possible when assuming currently codified tax rates and debt-to-equity ratio, providing equity capital is always favorable in Belgium because capital gains are exempt from taxation, thin capitalization rules discriminate debt financing and a notional interest deduction on equity capital is granted. Although an ACE often is regarded as a means to provide tax neutrality, in Belgium this neutrality property has been undermined by introducing a thin capitalization rule, which obviously exacerbates the discrimination of debt capital (Gerard 2006: 156).

\subsection{Assessment}

\subsubsection{Critical income tax rate}

The shareholder can optionally include dividends into the individual tax assessment. In this case dividends and interest are not subject to the withholding tax of $25 \%$ or $15 \%$ but to the shareholder's individual income tax rate. Hence, the option to include dividends or interest in the assessment is only reasonable for shareholders with an income tax rate less than $25 \%$ and $15 \%$ respectively. For simplicity we only consider the case that the choice to include income in the assessment is beneficial for both dividends and interest.

If dividends and interest income are included in the assessment, all sources of income are subject to the same income tax rate. Therefore, we have

$$
\tau_{i D}=\tau_{i I}=\tau_{i G}=\tau_{i} .
$$

The net profit is thus equal to

$$
\Pi_{\tau}=\Pi-\underbrace{\tau_{c}\left(\Pi-i C(1-\alpha)-i \mu E-i_{n} E\right)}_{T_{c}}
$$




$$
\begin{aligned}
& -\tau_{i} \varepsilon(i C(1-\alpha)+i \mu E) \\
& -\tau_{i} \gamma[D+i C \alpha-i \mu E] \\
& -\tau_{i} \lambda \theta\left(\Pi-\tau_{c}[\Pi-i C(1-\alpha)\right. \\
& \underbrace{\left.\left.-i \mu E-i_{n} E\right]-D-i C\right)}_{T_{i}} .
\end{aligned}
$$

We obtain the same optimal dividend policy as for Italy and for Germany. The investor is only indifferent towards debt and equity financing if $\tau_{i}=0$, namely if they have no taxable income, or if $\lambda \theta=\gamma$ (section 3.1). Otherwise full retention is always the optimal dividend policy.

We obtain the following critical income tax rate by differentiating equation (36) with respect to $C$ :

$$
\text { (37) } \begin{aligned}
\tau_{i}^{*}=[ & \left.\tau_{c}[C(1-\alpha)+\mu E]\right] \\
& \cdot[\varepsilon[C(1-\alpha)+\mu E]+\gamma(C \alpha-\mu E) \\
& \left.+\lambda \theta\left(\tau_{c}[C(1-\alpha)+\mu E]-C\right)\right]^{-1} .
\end{aligned}
$$

\subsubsection{Sensitivity Analysis}

Just like in the other countries the gross profit and the interest rates do not influence the investor's financing decisions. The other model parameters influence the critical income tax rate and therefore the financing decisions.

We assume

$$
\begin{gathered}
\tau_{c}=33 \% ; \tau_{i}^{\max }=15 \% ; i_{n}=3.442 \% ; \mathrm{i}=6 \% ; \\
C=€ 100,000 ; E=€ 1,000 ; \gamma=1 ; \\
\lambda=0 ; \varepsilon=1 ; \mu=1 ; \alpha=1 .
\end{gathered}
$$

The top tax rate $\tau_{i}^{\max }$ is equal to $15 \%$ because only shareholders with an income tax rate of less than $15 \%$ will decide to include dividends and interest income in their individual assessment. Inserting the assumptions into equation (37) we obtain

(38) $\tau_{i}^{*}=0.33 \%$.

All investors have a marginal income tax rate that is higher than the critical income tax rate. To conclude for all investors we have to abstract from the typically rather small group of investors with a marginal income tax rate between zero and $0.33 \%$. Therefore, all investors prefer to provide equity capital instead of debt capital. This result corre- sponds to that obtained for the withholding tax (section 5.1.2).

A variation of the factor $\theta$ has no influence on the critical income tax rate because capital gains are tax-exempt. Only if $\lambda>0$ will a change in the factor $\theta$ affect the investor's financing decisions. In these cases a change in this factor influences the financing decisions in the same way as a change in the taxable fraction of capital gains $\lambda$ does.

In line with the results for the other countries, we obtain a rising critical income tax rate and an increased relative advantage of debt capital if we assume a rising corporate tax rate (section 3.2.2). Varying the taxable fraction of dividends $\gamma$ while assuming that capital gains are tax-free leads to a negative derivative. We find that lowering $\gamma$ causes a rising advantage of debt capital (section 3.2.3):

$$
\frac{\partial \tau_{i}^{*}}{\partial \gamma}=\frac{-117,612}{(60+5,940 \gamma)^{2}}<0
$$

We obtain critical income tax rates higher than $15 \%$ and therefore an attractiveness of the withholding tax for interest income over the individual assessment for $\gamma<0.0121$.

Assuming a taxation of capital gains, i.e. $\lambda>0$, and a taxation of dividends to the full amount, i.e. $\gamma=1$, we obtain the following positive first derivative:

$$
\frac{\partial \tau_{i}^{*}}{\partial \lambda}=\frac{118,408 \theta}{(6,000-5,980 \lambda \theta)^{2}}>0
$$

As expected, implementing a capital gains tax invokes a higher relative advantage of debt capital (section 3.2.3). The effect of a rising $\lambda$ on the critical income tax rate is very low. We obtain critical income tax rates of over $15 \%$ only for very high capital gains taxes with only hypothetical relevance $(\lambda \theta>$ 0.98124).

A change in the taxable fraction of both dividends and capital gains $(\gamma=\lambda)$ leads to the following derivative that is a function of the value of the factor $\theta$ and may take positive or negative values:

$$
\frac{\partial \tau_{i}^{*}}{\partial \gamma}=\frac{-117,612+118,408 \theta}{(60+5,940 \gamma-5,980 \gamma \theta)^{2}} \gtreqless 0 .
$$

If $\theta>0.993$, the partial derivative is positive. If $\theta<0.993$, it is negative. 
As in the previously analyzed countries a decreasing fraction of considered debt leads to an increased critical income tax rate that implies an increasing advantage of debt capital (section 3.2.5). The derivative $\frac{\partial \tau_{i}^{*}}{\partial \alpha}$ is always negative. Lowering the fraction of considered debt $\alpha$ from 1 to 0.5 leads to a rise in the critical income tax rate from $0.33 \%$ to $16.83 \%$. Lowering $\alpha$ to 0.25 leads to $\tau_{i}^{*}=25.08 \%$. If $\alpha=0.5$, the investor therefore will decide in favor of the withholding tax for interest income. If $\alpha=0.25$, they will prefer the withholding tax for dividends.

Decreasing the taxable fraction of interest $\varepsilon$ we find a rise in the relative advantage of debt capital. The partial derivative $\frac{\partial \tau_{i}^{*}}{\partial \varepsilon}$ is always negative.

A rise in the permitted ratio of debt to equity capital $\mu$ or the amount of equity capital $E$ leads to an increase in the relative advantage of debt capital. The first derivatives $\frac{\partial \tau_{i}^{*}}{\partial \mu}$ and $\frac{\partial \tau_{i}^{*}}{\partial E}$ are always positive (section 3.2.5). To obtain a critical tax rate of more than $15 \%$ the permitted ratio of debt to equity capital has to be increased to $46: 1$ or debt capital has to be increased to $€ 46,000$.

\subsubsection{Results}

Assuming assessment is attractive for investors, their financing decisions depend, as in Italy and Germany, on their marginal income tax rate. The different model parameters exert an influence on the decision that corresponds to the one identified for the other countries. As in the case of the withholding tax, equity capital is always beneficial when considering currently codified tax rates and debt-to-equity-capital ratio because capital gains are exempt from taxation and a notional interest deduction is granted for equity capital. If the thin capitalization rule was abolished we would obtain a critical income tax rate that is equal to the corporate tax rate. This result is in line with the neutrality property of an ACE tax and implies that, given the assumption of a perfect capital market, we lose capital structure irrelevance as soon as the income tax rate differs from the corporate tax rate. The analysis of the Belgian tax system clarifies that, given a neutral corporate tax, the political aim to foster equity financing and prevent a drain of tax revenues due to debt financing, a thin capitalization rule with a given permitted debt-to-equity ratio may help to achieve this aim irrespective of the investors' income tax rates.

\section{Conclusions and future research}

From a tax planner's point of view, it is often attractive to choose debt over equity financing. Nevertheless, corporations issue shares as well as debt, raising the question on possible causes. As individual tax planning has led to an increase in debt financing of corporations, many countries have introduced thin capitalization rules to secure their tax revenues. These thin capitalization rules might explain why corporations still issue both debt and equity.

Against this background we investigate how such regulations affect the capital structure decisions of stockholders of corporations. We examine general thin capitalization rules and more specific and complex examples of regulations to restrict shareholder financing as to their impact on financing decisions of shareholders of corporations. The general case is exemplified by the Italian rules of the 2007 tax law and the more specific regulations are illustrated by the examples of the German and Belgian thin capitalization rules of the 2007 tax law. The selected rules can be regarded as representative examples of many countries' thin capitalization rules that are characterized by a permitted debt-to-equity ratio. As a corresponding regulation exists in several countries, the knowledge gained in our study can be used as the basis for follow-up empirical studies on the impact of thin capitalization rules on capital structure decisions in these countries.

Furthermore, as the financing behavior of investors is crucial for designing thin capitalization rules and as the influence of thin capitalization rules depends heavily on a lot of other tax parameters (corporate tax rate, taxable fraction of dividends and capital gains, permitted ratio of debt to equity capital) it is important for the treasury to know how these rules interact. Our results help the treasury to implement a rule that contributes to their given political aim in a given tax setting. Taking into account the relevant tax rates and the codified debt-equity ratio we find similar results for Italy and Germany. In particular, a so-called Miller equilibrium is possible when the difference of the corporate tax rate and the individual income tax rate is relatively low and when the provided debt comprises a small fraction of considered debt. The fraction of considered debt is presently only limited under the German-type rule because 
there only long-term debt is taken into account. In Belgium equity capital always incorporates an advantage considering current tax rates and the current debt-to-equity-capital ratio because even though Belgium has introduced a supposedly neutral ACE tax debt capital is discriminated by a thin capitalization rule. This result holds in the case of both withholding tax and assessment.

Investigating changes in the model parameters we obtain similar results for all underlying tax systems. In particular, varying the fraction of considered debt as well as the ratio of corporate tax rate and income tax rate and the permitted ratio of debt to equity capital have a substantial impact on the critical income tax rate and make a Miller equilibrium possible. Among these parameters, only the permitted ratio of debt to equity capital and the tax rates can be influenced by the legislator. The remaining parameters can be changed by the taxpayers themselves.

There is a broad range of issues that should be addressed in future research. Although the present analysis only focuses on individual shareholders, corporate shareholders can easily be integrated into the model by changing the denotation "income tax" to "corporate tax" on the shareholder level and changing the values of the taxable fraction of dividends $\gamma$ and capital gains $\lambda$ in the sensitivity analysis. As thin capitalization rules, especially in Europe, are applicable to both domestic and foreign investors, for simplicity we focus only on domestic shareholders. An extension of the model with respect to international investors is possible. Effects on financing decisions arising from international tax base or tax rate differentials are captured in our sensitivity analysis in sections 3.2, 4.2, 5.1.2 and 5.2.2. The basic results remain the same in the international context. In the case of different interpretations of income (dividend or interest income) that has been requalified as dividends under a thin capitalization rule we have to fall back on a single-case analysis. General results can no longer be deduced.

In 2008 both Germany and Italy (see Marino and Russo 2008 for an overview of the new Italian regulation) changed their thin capitalization rules and implemented an interest barrier. Under Germany's 2008 business tax reform (section $4 \mathrm{~h}$ of the Income Tax Code and section 8a of the German Corporate Tax Code as amended by the German Business Reform dated Aug. 14, 2007, BGBl. I
2007: 1913 et seq., 1927 et seq.), in principle interest payable is deductible up to an amount that corresponds to the interest earned by the company. The residual interest payable can be deducted from the tax base up to an amount of $30 \%$ of the residual profit, plus depreciation and interest expenses and less interest income. Interest expenses that remain non-deductible according to this regulation have to be carried forward and, subject to the same conditions, increase interest expenses in subsequent financial years. In this regard, the non-deductible interest expenses are not classified as hidden distribution of profit. Hence, on the shareholder level they are treated as interest income. The tax allowance up to which the regulation is not applied amounts to $€ 3,000,000$. With respect to the interest barrier, initially only statements about the tendency can be made.

On the corporate level debt capital is advantageous, because interest payments are at least partially taxdeductible, whereas dividends and capital gains are not. In contrast, on the shareholder level interest income is fully taxable and subject to the shareholder's individual income tax rate (see Appendix A1). A withholding tax amounting to $25 \%$ is on principle levied on dividends and capital gains (see Kiesewetter and Lachmund 2004 who investigate and demonstrate the effects of a final withholding tax on the capital structure of enterprises with the help of investment appraisal and who design, based on the achieved results, a withholding tax that is independent of the financing form). The shareholder can also choose to include dividends and capital gains in their assessment. A substantial shareholder with a holding of at least $25 \%$ can additionally choose a shareholder relief system for dividends and capital gains. In this case they are subject to the shareholder's individual income tax rate, but only taxed at a fraction of $60 \%$. The shareholder relief system is always advantageous unless the shareholder exhibits an individual income tax rate of $42 \%$. To sum up, dividends and capital gains are usually lower taxed on the shareholder level than interest income. Hence, capital structure irrelevance is possible since the lower taxation of income from equity on the shareholder level counteracts the lower taxation of income from interest on the company level caused by the (partial) deductibility of interest payments. If the capital company incurs losses over a longer period and interest payments hence cannot be de- 
ducted in the same period, the attractiveness of equity financing compared to debt financing increases. In the extreme case, if interest on debt cannot be deducted at all, equity financing always generates the highest net profit.

To gain more precise results for Germany a quantitative analysis including all items of Germany's 2008 Tax Reform Act is necessary. Furthermore, an analysis of the new Italian thin capitalization rules and a comparison of the results of the German and Italian regulation is reasonable. We relegate this issue to future research.

For now, our analysis highlights that for companies in countries with thin capitalization rules and a permitted debt-equity ratio, debt financing can typically be tax-optimized by shareholders. However, under certain circumstances the capital structure can become irrelevant.

\section{Appendix}

\section{A1: Supplementary information on the national tax laws}

\section{Belgium}

The Belgian thin capitalization rule was introduced in 1997 and is still in force.

Belgium raises a surcharge of $3 \%$ of the corporate tax. We neglect this surcharge.

Belgium raises local surcharges on the income tax. We neglect these local surcharges.

\section{Germany}

The German thin capitalization rule was introduced in 2004. It has been reformed by the German business tax reform act 2008 where it was substituted by an interest barrier.

From 2008 on the local business tax is not deductible as an operating expense anymore.

The half-income system was abolished in 2009 and replaced by a final flat tax on capital income of $25 \%$. A modified shareholder relief system is only applicable to capital income from corporate shares held as business assets. Substantial shareholders with a shareholding of at least $25 \%$ can choose between the withholding tax and the shareholder relief system.

From 2009 on a withholding tax amounting to $25 \%$ is on principle levied on dividends and capital gains. The withholding tax is not applicable to a shareholding of at least $10 \%$ (see section $32 \mathrm{~d}$ of the Income Tax Code for an overview of the taxation of income from equity capital).

\section{Italy}

We consider Italy's thin capitalization rule in 2007. For an overview of this regulation see, for example, Gusmeroli and Russo (2004). This regulation was introduced in 2004. In 2008 Italy replaced its former rules with a regulation similar to the new German interest barrier. See Marino and Russo (2008) for an overview of this new regime.

\section{A2: Supplementary information on the analysis}

We assume that the thin capitalization rule applies to all shareholders and thus to all investors. The thin capitalization rule is for example applicable to all shareholders in Belgium and Spain. In many other countries, including Germany, Italy, the Netherlands and Portugal, thin capitalization rules only apply to what are known as substantial shareholders. These are shareholders with a given minimum shareholding. Loans from third parties and non-substantial shareholders can easily be integrated into the model. As interest payments to third parties and to non-substantial shareholders do not induce a thin capitalization treatment, these extensions do not yield any new insights for our analysis.

We assume that a fraction $\alpha$ of debt is subject to the thin capitalization rule. In Germany the regulation only applies to interest paid on long-term debt. Other countries apply the regulation to all interest payments to specific shareholders.

The values in Table 1 neglect that the factor $\theta$ should be endogenously determined. As the influence of $\tau_{i}^{*}$ on $\theta$ cannot be derived analytically we have to fall back on simulation. To point out that the resulting changes in our results are very small we have performed an iterative simulation. By iteration we can account for the interdependency of $\tau_{i}^{*}$ and $\theta$. We find that the resulting critical tax 
rates are slightly higher. At a maximum we identify a deviation of 3.75 percentage points from the rates determined for an exogenously given $\theta$. We find similar deviations if we vary other model parameters. Against this background, it is acceptable to conduct the following investigation abstracting from this interdependency. We hence do not have to fall back on numerical results on optimal capital structure; instead, analytical and thus more general results can be obtained.

In Germany the investor is indifferent towards dividend policy if the income tax rate $\tau_{i}=0$ or if the factor $\theta=\frac{\gamma}{\lambda}$. The condition $\tau_{i}=0$ is true if the taxable income of the investor is lower than the basic allowance of $€ 7,664$ for singles and $€ 15,328$ for married couples (see section 32a of the Income Tax Code).

The values in Table 2 neglect the influence of $\tau_{i}^{*}$ on $\theta$. By iteration we can show that the critical tax rates are slightly higher. At a maximum we identify a deviation of 0.6 percentage points from the rates determined for an exogenously given $\theta$. We find similar deviations if we vary other model parameters.

\section{Acknowledgements}

We are indebted to two anonymous referees and the department editor, Rainer Niemann, for their very valuable suggestions, which helped to improve the paper considerably. We thank the participants of the European Accounting Association Annual Congress 2008 in Rotterdam and 2009 in Tampere for fruitful discussions. Furthermore, we are particularly grateful for very helpful comments from Rolf König and Lutz Kruschwitz. The usual disclaimer applies.

\section{References}

Boadway, Robin and Neil Bruce (1979): Depreciation and interest deductions and the effect of the corporation income tax on investment, Journal of Public Economics, 11 (1): 93-105.

Brennan, Michael J. (1970): Taxes, Market Valuation and Corporate Financial Policy, National Tax Journal, 23 (4): 417-427.

Buettner, Thies, Michael Overesch, Ulrich Schreiber, and Georg Wamser (2006): The Impact of Thin-Capitalization Rules on Multinationals' Financing and Investment Decisions, ZEW Discussion Paper No. 06-068: Mannheim.

Cowley, Nick, Carlos Gutiérrez, Juhani Kesti, and Mei-June Soo (eds.) (2008): Global Corporate Tax Handbook 20o8, International Bureau of Fiscal Documentation: Amsterdam.
DeAngelo, Harry and Ronald W. Masulis (1980a): Optimal Capital Structure under Corporate and Personal Taxation, Journal of Financial Economics, 8 (1): 3-29.

DeAngelo, Harry and Ronald W. Masulis (1980b): Leverage and Dividend Irrelevancy under Corporate and Personal Taxation, Journal of Finance, 35 (2): 453-464.

Desai, Mihir A., C. Fritz Foley, and James R. Hines (2004): A Multinational Perspective on Capital Structure Choice and Internal Capital Markets, Journal of Finance, 59 (6): 24512487.

Devereux, Michael and Harold Freeman (1991): A General Neutral Profits Tax, Fiscal Studies, 12 (3): 1-15.

Donaldson, Gordon (1961): Corporate Debt Capacity: A Study of Corporate Debt Policy and the Determination of Corporate Debt Capacity, Division of Research, Graduate School of Business Administration, Harvard University: Boston.

Farrar, Donald E. and Lee L. Selwyn (1967): Taxes, Corporate Financial Policy, and Return to Investors, National Tax Journal, 20 (4): 444-454.

Federal Statistical Office (2007): Trade tax rates rose slightly on a federal average in 2006, press release dated 08/22/2007, http://www.destatis.de/jetspeed/portal/cms/Sites/destatis/ Internet/EN/press/pr/2007/o8/PEo7_329_735.psml. (Access Date: 2009-01-29).

Fehr, Hans and Wolfgang Wiegard (2003): ACE for Germany? Fighting for a Better Tax System, in: Michael Ahlheim, HeinzDieter Wenzel, and Wolfgang Wiegard (eds.), Steuerpolitik Von der Theorie zur Praxis: Festschrift für Manfred Rose, Springer: Berlin et al., 297-324.

Fischer, Edwin O., Robert Heinkel, and Josef Zechner (1989): Dynamic Capital Structure Choice: Theory and Tests, Journal of Finance, 44 (1): 19-40.

Fung, William K.H. and Michael F. Theobald (1984): Dividends and Debt under Alternative Tax Systems, Journal of Financial and Quantitative Analysis, 19 (1): 59-72.

Gerard, Marcel (2006): Belgium Moves to Dual Allowance for Corporate Equity, European Taxation, 46 (4): 156-162.

Gouthière, Bruno (2005): A Comparative Study of the Thin Capitalization Rules in the Member States of the European Union and Certain Other Countries, European Taxation, 45 (9-10): 367-451.

Graham, John R. (2000): How Big are the Tax Benefits of Debt?, Journal of Finance, 55 (5): 1901-1941.

Graham, John R. (2003): Taxes and Corporate Finance: A Review, The Review of Financial Studies, 16 (4): 1075-1129.

Graham, John R. (2006): A Review of Taxes and Corporate Finance, Foundations and Trends in Finance, 1 (7): 573-691.

Gusmeroli, Michele and Massimiliano Russo (2004): Italian Thin Capitalization Rules, Tax Treaties and EC Law: Much Ado About Something, Intertax, 32 (10): 493-519.

Harris, Milton and Artur Raviv (1991): The Theory of Capital Structure, Journal of Finance, 46 (1): 297-355.

Haugen, Robert A. and Lemma W. Senbet (1978): The Insignificance of Bankruptcy Costs to the Theory of Optimal Capital Structure, Journal of Finance, 33 (2): 383-393.

Hodder, James E. and Lemma W. Senbet (1990): International Capital Structure Equilibrium, Journal of Finance, 45 (5): 1495-1516.

Holland, Susanne and Peter Steiner (1996): Zum Einfluß des Solidaritätszuschlags auf die Kapitalstruktur deutscher Kapitalgesellschaften, Journal für Betriebswirtschaft, 46 (2): 67-75. 
Huizinga, Harry, Luc Laeven, and Gaëtan Nicodème (2006): Capital Structure and International Debt Shifting in Europe, ETPF Research Paper, European Tax Policy Forum: London.

International Bureau of Fiscal Documentation (2006): European Tax Handbook 2006, C.F. IBFD: Amsterdam.

Jensen, Michael C. and William H. Meckling (1976): Theory of the Firm: Managerial Behavior, Agency Costs and Ownership Structure, Journal of Financial Economics, 3 (4): 305-360.

Kiesewetter, Dirk and Andreas Lachmund (2004): Wirkungen einer Abgeltungssteuer auf Investitionsentscheidungen und Kapitalstruktur von Unternehmen, Die Betriebswirtschaft, 64 (4): 395-411.

Kim, E. Han (1978): A Mean-Variance Theory of Optimal Capital Structure and Corporate Debt Capacity, Journal of Finance, 33 (1): 45-63.

Kim, E. Han (1982): Miller's Equilibrium, Shareholder Leverage Clienteles, and Optimal Capital Structure, Journal of Finance, 37 (2): 301-319.

Kraus, Alan and Robert H. Litzenberger (1973): A StatePreference Model of Optimal Financial Leverage, Journal of Finance, 28 (4): 911-922.

Kruschwitz, Lutz (2007): Finanzierung und Investition, 5th ed., Oldenbourg: München et al.

Laß, Frank (1999): Der Einfluß der Besteuerung auf unternehmerische Finanzierungsentscheidungen, Shaker: Aachen.

Leland, Hayne E. (1998): Agency Costs, Risk Management, and Capital Structure, Journal of Finance, 53 (4): 1213-1243.

Litzenberger, Robert H. and James C. van Horne (1978): Elimination of the Double Taxation of Dividends and Corporate Financial Policy, Journal of Finance, 33 (3): 737-750.

Marino, Tancredi and Massimiliano Russo (2008): Italian Restyling of Interest Deduction Rules: the Amendments of the Italian Finance Bill for 2008, Intertax, 36 (5): 204-210.

Maßbaum, Alexandra and Caren Sureth (2008): The Impact of Thin Capitalization Rules on Shareholder Financing, http://www.arqus.info/paper/arqus_39.pdf (Access Date: 2009-11-10).

Miller, Merton H. and Myron S. Scholes (1978): Dividends and Taxes, Journal of Financial Economics, 6 (4): 333-364.

Mintz, Jack and Alfons J. Weichenrieder (2005): Taxation and the Financial Structure of German Outbound FDI, CESifo Working Paper 1612, Center for Economic Studies: Munich.

Modigliani, Franco and Merton H. Miller (1958): The Cost of Capital, Corporation Finance and the Theory of Investment, American Economic Review 48 (3): 261-297.

Modigliani, Franco and Merton H. Miller (1963): Corporate Income Taxes and the Cost of Capital: a Correction, American Economic Review, 53 (3): 433-443.

Myers, Stewart C. (1984): The Capital Structure Puzzle, Journal of Finance, 39 (3): 575-592.

Myers, Stewart C. (2001): Capital Structure, Journal of Economic Perspectives, 15 (2): 81-102.

OECD (1987): Issues in International Taxation, No 2, Thin Capitalization: Organisation for Economic Co-Operation and Development: Paris.

Offermanns, René (2006): Belgium, in: Juhani Kesti (ed.): European Tax Handbook 20o6, International Bureau of Fiscal Documentation, Amsterdam: 63-82.
Overesch, Michael and Georg Wamser (2006): German Inbound Investment, Corporate Tax Planning, and ThinCapitalization Rules - a Difference-in-Differences Approach, Discussion Paper No. 06-075, Zentrum für Europäische Wirtschaftsforschung: Mannheim.

Overesch, Michael and Georg Wamser (2009): Corporate Tax Planning and Thin-Capitalization Rules: Evidence from a Quasi-Experiment, Applied Economics, forthcoming.

Romanelli, Luca (2006): Italy, in: Juhani Kesti (ed.): European Tax Handbook 2006, International Bureau of Fiscal Documentation, Amsterdam: 363-382.

Schneller, Meir I. (1980): Taxes and the Optimal Capital Structure of the Firm, Journal of Finance, 35 (1): 119-127.

Swoboda, Peter (1991): Irrelevanz oder Relevanz der Kapitalstruktur und Dividendenpolitik von Kapitalgesellschaften in Deutschland und Österreich nach der Steuerreform 1990 bzw. 1989?, Zeitschrift für betriebswirtschaftliche Forschung, 43 (10): 851-866.

Weichenrieder, Alfons J. and Helen Windischbauer (2008): Thin-Capitalization Rules and Company Responses. Experience from German Legislation, CESifo Working Paper 2456, Center for Economic Studies: Munich.

Wenger, Ekkehard (1983): Gleichmäßigkeit der Besteuerung von Arbeits- und Vermögenseinkünften, Finanzarchiv, 41 (2): 207-252.

Zechner, Josef (1990): Tax Clienteles and Optimal Capital Structure under Uncertainty, The Journal of Business, 63 (4): 465-491.

\section{Biographies}

Alexandra Maßbaum is doctoral student and research assistant at the Chair of Business Administration, esp. Business Taxation at the University of Paderborn. She received her diploma degree in Business Administration with specialization in accounting, taxation, auditing, and management accounting, as well as corporate and tax law from the University of Osnabrück.

Caren Sureth is Professor and Chair of Business Administration, esp. Business Taxation since 2004 and also Head of the Center for Tax Research at the Unversity of Paderborn. She received her doctorate from the University of Bielefeld, where she also reached her habilitation. She studied Business Administration, English, French, and Chinese and received her Diploma Degree at the University of Passau. Her main fields of research are the impact of taxation on entrepreneurial decisions, tax planning, and taxation under uncertainty. 